\title{
Effects of Biochar Application in a Sorghum Crop under Greenhouse Conditions: Growth Parameters and Physicochemical Fertility
}

\author{
María Videgain-Marco ${ }^{1, *(\mathbb{D}, \text { Pedro Marco-Montori }}{ }^{2}\left(\mathbb{D}\right.$, Clara Martí-Dalmau $^{1}(\mathbb{D}$, \\ María del Carmen Jaizme-Vega ${ }^{3}$, Joan Josep Manyà-Cervelló ${ }^{4}$ (D) and \\ Francisco Javier García-Ramos ${ }^{1}$ (D) \\ 1 Departamento de Ciencias Agrarias y del Medio Natural, EPS, Universidad de Zaragoza, Carretera de \\ Cuarte s/n, E-22071 Huesca, Spain; cmarti@unizar.es (C.M.-D.); fjavier@unizar.es (F.J.G.-R.) \\ 2 Instituto Agroalimentario de Aragón-IA2 (CITA-Universidad de Zaragoza), Unidad de Recursos Forestales, \\ Centro de Investigación y Tecnología Agroalimentaria del Gobierno de Aragón (CITA), Avenida Montañana \\ 930, E-50059 Zaragoza, Spain; pmarcomo@cita-aragon.es \\ 3 Departamento de Protección Vegetal, Instituto Canario de Investigaciones Agrarias (ICIA), Carretera de El \\ Boquerón s/n, Valle Guerra, La Laguna, E-38270 Tenerife, Spain; mcjaizme@icia.es \\ 4 Aragón Institute of Engineering Research (I3A), Biochar Research Lab, EPS, University of Zaragoza, \\ Carretera de Cuarte s/n, E-22071 Huesca, Spain; joanjoma@unizar.es \\ * Correspondence: mvidegain@unizar.es; Tel.: +34-974292656
}

Received: 25 November 2019; Accepted: 8 January 2020; Published: 10 January 2020

\begin{abstract}
Application of biochar from vine shoots (Vitis vinifera L.) as an organic amendment in the soil is an alternative agricultural management of interest. The behavior of this type of amendment in the soil requires more information to adjust the pyrolysis conditions in order to obtain a high-quality biochar. The aim of this work is determining the influence of the application of this type of biochar on the soil-plant system. For this purpose, an agronomic test was performed in greenhouse pots. A randomized tri-factorial block design was adopted with the following factors: final pyrolysis temperature $\left(400\right.$ and $\left.600{ }^{\circ} \mathrm{C}\right)$, application rate $(0 \mathrm{wt}$. \% as a control, 1.5 and $3 \mathrm{wt}$. \%) and texture of the growing media (sandy-loam and clay-loam origin). The selected crop was sorghum (Sorghum bicolor L. Moench), the development and production of which was evaluated during two complete growing cycles under greenhouse conditions. Application of biochar produced at $400{ }^{\circ} \mathrm{C}$ significantly increased plants roots dry weight in the sandy-loam growing substrate ( $52 \%$ compared to the control). Grain production was also significantly affected by biochar application, showing better results after addition of biochar produced at $400{ }^{\circ} \mathrm{C}$. Water holding capacity and $\mathrm{K}, \mathrm{Ca}$, and $\mathrm{Mg}$ contents were enhanced by biochar addition, with evident effects of the application ratios for some of these variables. The effect on the $\mathrm{pH}$ of substrates in the sandy-loam texture was weak; however, a significant decrease was observed after the addition of biochar produced at $600^{\circ} \mathrm{C}$.
\end{abstract}

Keywords: carbon sequestration; organic amendment; pyrolysis; vineyard pruning; vine shoots

\section{Introduction}

One of the traditional ways to improve the energy efficiency of agricultural systems is to return to the soil part of the biomass produced by crops, which in many cases is removed from the field to be used for other purposes or even destroyed.

Returning crop waste into the soil, either without any processing or through organic amendments, represents a management strategy that, in addition to the improvement of energy efficiency for agroecosystems, may help to combat soil degradation phenomena. In Spain, almost $74 \%$ of the territory 
is susceptible to desertification due to climatic reasons and human activity, among which agricultural management methods acquire relevant importance [1].

An alternative to returning biomass into the soil is the integration of biochar as an organic amendment in the crop production process. The term biochar can be defined as a carbonaceous material obtained from biomass by thermal decomposition at low or no oxygen concentration, through a thermochemical process known as pyrolysis [2]. There is also a scientific consensus that its specific application to soil is expected to sustainably sequester carbon and improve the soil functions [3,4].

A growing number of previous studies have emerged describing diverse aspects of biochar regarding its production, characterization, and application [5-9]. However, there is a broad spectrum of results when analyzing the biochar application effects on soil physical, chemical, and biological fertility. The degree of knowledge about the effect of biochar on the soil-plant-microorganisms system is very recent and the results already published are contradictory and dependent on the specificity of the experiment conducted [5,10-14].

Final properties of biochar (porosity, ash content, total fixed carbon content, available nutrients, etc.) depend on the pyrolysis operating conditions (e.g., temperature and pressure conditions, and residence time of the gas phase within the reactor), which also play a key role on the process performance [15-18]. Besides these conditions, it is necessary to consider the nature of selected feedstock (in terms of composition, moisture and granulometry) $[18,19]$, which could also affect the pyrolysis process itself and the final behavior of resulting biochar in the soil. The differences in the physicochemical properties of biochars obtained from different precursors at different operating conditions can allow researchers to produce tailored products for specific purposes. In general, a higher lignin content is responsible for the development of a macroporous structure, whereas a relatively higher cellulose content yields a microporous one [20]. The final pore size distribution determines its hydraulic properties, the improvement of which has widely been reported in earlier studies for wood-derived biochar [21-23].

Biochar application as a soil amendment is motivated by its capacity to enhance crop yields and alter the soil physical and chemical properties, such as soil water holding capacity (WHC), $\mathrm{pH}$, cation exchange capacity (CEC), nutrient retention, and organic carbon [22,24,25]. Nevertheless, this influence is strongly dependent on biochar final temperature production, particle size, soil texture and mineralogy [26,27]. In fact, the largest effects has been observed for acidic and sandy texture soils $[28,29]$. In addition, the biochar application rate (into the soil) is also an important factor, which can influence both the crop response and modification of soil parameters. In this regard, dose-response relationships have been reported as linear [30,31] and not linear [26,32-34], thus suggesting that many research efforts are needed to better clarify the influence of the biochar application rate.

Due to the high volume of vine shoots offered every year from vineyard winter pruning [35] as well as problems related to plant diseases derived from a direct application of theses residues into the soil [36], conversion of vine shoots into biochar and its subsequent application to the field (towards an improvement of soil quality) appears to be a sustainable and very attractive alternative.

Since relatively little information is available regarding the application of this type of biochar as an organic amendment [37-39], our study aims at achieving a wide understanding on the influence of different factors (such as the final pyrolysis temperature, biochar application rate, and soil texture) on the crop response variables. Outcomes from this kind of assessment studies will help researchers and agricultural advisors to make decisions concerning the viability of using biochar as a soil amendment in agricultural lands. To this aim, sorghum (Sorghum bicolor L. Moench) was selected as a test crop. A bioassay was conducted in pots under controlled greenhouse conditions. This work collects the information about the effects of biochar application on the crop growth parameters and some physicochemical properties of the soils studied. Previous studies $[40,41]$ have reported positive responses of these variables to biochar addition in sorghum crop. Previous experience on the study of operating conditions for vine shoots slow pyrolysis process (at low temperatures in the range of $\left.300-700^{\circ} \mathrm{C}\right)[18,40,42,43]$ and other studies in the same line of research $[36,44,45]$, have allowed us to develop this work in a logical way, starting from a properly characterized biochar. 


\section{Materials and Methods}

\subsection{Biomass Feedstock Collection and Characterization}

Vine shoots (Vitis vinifera L.) were used as biochar precursor. They were collected during winter pruning in a winery located in the D.O. Somontano, northeast of Aragón (Aragón, Spain). The grape variety was Cabernet Sauvignon with two different rootstocks and in maximum production stage (average Ravaz index of 6).

The collected feedstock was stored in cardboard boxes to allow drying before processing. Vine shoots were selected by diameter (between 8.5 and $15 \mathrm{~mm}$ ) and they were then cut using a domestic chipper into smaller pieces of $4-7 \mathrm{~cm}$ in length.

For a representative biomass sample, proximate analyses were performed following standardized procedures published by the American Society for Testing and Materials (ASTM) [46] (D3173 for moisture, D3174 for ashes, and D3175 for volatile matter), which are commonly used for coal and charcoal characterization. The moisture content was calculated from the mass loss at $105^{\circ} \mathrm{C}$. From the mass loss obtained at $950{ }^{\circ} \mathrm{C}$ under an $\mathrm{O}_{2}$-free atmosphere, the content of volatile matter was estimated. The final mass obtained after heating the remaining biochar up to $750{ }^{\circ} \mathrm{C}$ in air led to the ash content. Finally, the fixed-carbon content was calculated by difference. Elemental analysis was also conducted using an elemental micro CHNS analyzer from LECO (St. Joseph, MI, USA). Ash composition was analyzed according to ASTM D4326-04 through X-ray fluorescence (XRF) using an ADVANT'XP + XRF spectrometer from Thermo ARL (Ecublens, Switzerland).

The contents of the main constituents of the biomass feedstock (lignin + silica, cellulose, carbohydrate + protein, and hemicellulose + acid soluble ash) were determined according to the Van Soest method [47]. Organic extractives were previously extracted using a mixture of ethanol and toluene $(1: 2 \mathrm{v} / \mathrm{v})$ as solvent.

\subsection{Biochar Production, Characterization, and Processing}

Pyrolysis experiments were conducted in a fixed-bed laboratory reactor. It consisted of a cylindrical and vertical reactor (140 mm ID; $465 \mathrm{~mm}$ long) made of Sandvik $253 \mathrm{MA}^{\mathrm{TM}}$ stainless steel (Demede, Madrid, Spain) and heated by two electric resistances of $2.1 \mathrm{~kW}$ with proportional integral derivative (PID) temperature control. A basket of $4 \mathrm{~L}$, made of AISI 316 stainless steel wire mesh, was used to put the biomass into the reactor. The temperature inside of the bed was measured using four thermocouples placed in a thermowell at different heights. More details about the configuration of the reactor are available in previous publications [18,48]. A total of 13 experiments were carried out at two different final pyrolysis temperatures at atmospheric pressure. Approximately $500 \mathrm{~g}$ of vine shoots were heated at an average heating rate of $5^{\circ} \mathrm{C} \mathrm{min}^{-1}$ to the final temperature $\left(400\right.$ and $\left.600{ }^{\circ} \mathrm{C}\right)$ with a soaking time of $60 \mathrm{~min}$ at this temperature. The mass flow rate at standard temperature and pressure (STP) conditions of the carrier gas $\left(\mathrm{N}_{2}\right)$ was adjusted to keep a constant real flow rate of $\mathrm{N}_{2}$ within the reactor (at the corresponding final temperature) of $1.8 \mathrm{~L} \mathrm{~min}^{-1}$, which corresponds to a carrier gas residence time of $180 \mathrm{~s}$. The particle size adopted resulted appropriate to improve the carbonization efficiency (i.e., higher fixed-carbon content in the resulting biochar) during pyrolysis process because of the enhancement of secondary charring reactions at an intra-particle level [18,39].

Proximate and elemental analyses were performed for each biochar following the standards specified above. In addition, biochar samples were sent to an external certified soils laboratory in order to analyze the several crop nutrients of biochar using an organic amendment as reference.

Due to the highly microporous structure of biochar, specific surface area $\left(\mathrm{S}_{\mathrm{BET}}\right)$ and pore volumes ( $\mathrm{V}_{\text {total }}$ and $\mathrm{V}_{\text {ultra }}$ for total micropores and narrow micropores or ultra-micropores, respectively) were determined from the $\mathrm{CO}_{2}$ adsorption isotherms at $0{ }^{\circ} \mathrm{C}$ (using an ASAP 2020 gas sorption analyzer from Micromeritics, Norcross, GA, USA) and assuming a Density Functional Theory (DFT) model for slit-pore geometry [43]. 
The obtained biochars were mechanically processed through an automatic agitation system, which was specifically designed to reproduce product movement in a regular fertilizer spreader. A detailed scheme of the agitation system is shown in Figure S1 (Supplementary Material). Approximately $150 \mathrm{~g}$ of biochar were introduced into the agitation system, which was powered by a combined drill (BL 18V LXT $115 \mathrm{Nm}$, Makita, Madrid, Spain) at the main speed of $50 \mathrm{rpm}$ for approximately $2 \mathrm{~min}$. The resulting biochar (keeping the same particle size distribution than that obtained after agitation) was used for the agronomic test.

\subsection{Phytotoxicity Test}

Biochars were evaluated for phytotoxicity according to the test proposed by Zucconi et al. [49] and applied in similar studies by other authors [50]. The test was conducted for five different species: watercress (Lepidium sativum, L.), barley (Hordeum vulgare L.), lettuce (Lactuca sativa L.), basil (Ocimum basilicum L.) and sorghum (Sorghum bicolor L.).

A total of 20 seeds of each species were distributed in three-replicated Petri dishes with $5 \mathrm{~mL}$ of biochar extract (1:10) poured over sterile filter paper. All Petri dishes were incubated at $25^{\circ} \mathrm{C}$ in the dark. After $72 \mathrm{~h}$, root length was measured and the germination index (GI) was calculated as described below:

$$
\mathrm{GI}=\left(\mathrm{G} / \mathrm{G}_{0}\right) \times\left(\mathrm{L} / \mathrm{L}_{0}\right)
$$

where $G$ and $G_{0}$ are the germination percentages ( $\mathrm{G}$ - biochar extract; $\mathrm{G}_{0}$-distilled water-control) and $\mathrm{L}$ and $\mathrm{L}_{0}$ are the mean of the root lengths of the samples and the control, respectively.

\subsection{Selection and Sampling of Bioassay Soils}

Soil texture was one of the factors considered evaluating the influence of biochar on the crop response. Soils under organic management with two contrasting textures (Soil 1 Calcisol—sandy-loam; Soil 2 Cambisol-clay-loam) were selected. A 10-point sampling from the top $30 \mathrm{~cm}$ was performed with an auger to obtain a representative soil sample. Samples were air-dried in the laboratory and sieved through a $2 \mathrm{~mm}$ mesh. A physicochemical analysis was performed. The following parameters were analyzed: $\mathrm{pH}$ (potenciometry), electrical conductivity (electrometry), oxidable organic matter (espectrofotometry), $\mathrm{N}$ ( $\mathrm{N}-\mathrm{NO}_{3}$-espectrofotometry), $\mathrm{P}$ (Olsen-espectrofotometry), $\mathrm{K}$ and $\mathrm{Mg}$ (ammonium acetate extract buffered at $\mathrm{pH}$ 7) and water holding capacity (WHC_-gravimetry-difference in water content between field capacity and permanent wilting point through Richards chamber). Table S1 reports detailed properties for both soils.

\subsection{Bioassay Experimental Design}

An agronomic experiment growing sorghum crop (Sorghum bicolor L. Moench) in pots was conducted under controlled greenhouse conditions. Both soil types were mixed with sterilized fine gravel $(60: 40 \mathrm{v} / \mathrm{v})$ to avoid soil compaction in the containers forming two final mixtures to receive biochar incorporation. A randomized factorial block design was adopted with the following factors as independent variables:

- Factor 1: growing media texture (S1—substrate 1—sandy-loam growing media; S2—substrate 2-clay-loam growing media).

- Factor 2: final pyrolysis temperature (B1-biochar $1-400{ }^{\circ} \mathrm{C}$; B2-biochar $2-600^{\circ} \mathrm{C}$ ).

- Factor 3: biochar application rate (D0—control—without biochar; D1-1.5 wt. \%; D2-3 wt. \%).

Five replicates were established for the 10 treatments: S1D0, S1B1D1, S1B1D2, S1B2D1, S1B2D2, S2D0, S2B1D1, S2B1D2, S2B2D1, S2B2D2; therefore, a total of 50 pots were filled with the mixtures and planted. 


\subsection{Bioassay Establishment and Development}

Greenhouse bioassay was installed in November 2017. Polyethylene trays with twelve fillers of $650 \mathrm{~cm}^{3}$ volume capacity, $18 \mathrm{~cm}$ deep, and $64 \mathrm{~cm}^{2}$ of the upper surface, were used for carrying out the bioassay. The pots were filled with the growing substrate mixture (soil + fine gravel), and the corresponding amount of biochar was homogeneously added to each one.

Chemically untreated sorghum seeds were pre-germinated and previously sterilized in tempered bleach solution ( 1 vol. \%) for $30 \mathrm{~min}$. Three pre-germinated seeds per tray filler were placed and carefully watered for two months until a thinning was performed (maintaining one plant per tray filler).

Temperature and relative humidity control at the greenhouse were controlled through a temperature/humidity sensor HOBO Pro v2 (Onset, Bourne, MA, USA), allowing us to adjust the intervals and irrigation rates during the crop cycle, considering crop evapotranspiration $(30 \mathrm{~mL}$ of water/irrigation interval). Leached water was collected and weighed in separate trays in order to adjust water needs to $70-80 \%$ of field capacity. Throughout the first four months of crop development, plants were watered only with water. At the end of the fourth month, all the plants began to present nutrient deficiency symptoms; therefore, a Hewitt nutritive solution with minimum phosphorus concentration $\left(\mathrm{P}^{-}\right)$[51] was added to water them for the rest of the experiment (composition $1 \mathrm{~L}: 0.4044 \mathrm{~g} \mathrm{NO}_{3} \mathrm{~K}$; $0.9446 \mathrm{~g} \mathrm{NO} 3 \mathrm{Ca} \cdot 4 \mathrm{H}_{2} \mathrm{O} ; 0.3697 \mathrm{~g} \mathrm{SO}_{4} \mathrm{Mg} \cdot 7 \mathrm{H}_{2} \mathrm{O} ; 0.027 \mathrm{~g} \mathrm{PO}_{4} \mathrm{H}_{2} \mathrm{~K} ; 0.0421 \mathrm{~g}$ Na EDTA-Fe; $0.00223 \mathrm{~g}$ $\mathrm{SO}_{4} \mathrm{Mn} \cdot 4 \mathrm{H}_{2} \mathrm{O} ; 0.00309 \mathrm{~g} \mathrm{BO}_{3} \mathrm{H}_{3} ; 0.000288 \mathrm{~g} \mathrm{SO} \mathrm{Zn}_{2} \cdot 2 \mathrm{H}_{2} \mathrm{O}$, and $0.00025 \mathrm{~g} \mathrm{SO}_{4} \mathrm{Cu} \cdot 5 \mathrm{H}_{2} \mathrm{O}$ ). Greenhouse conditions enabled cushioning outside temperatures-in any case, the temperature range reached inside along the year was broad (from $2.6^{\circ} \mathrm{C}$ minimum winter temperatures to $37.0^{\circ} \mathrm{C}$ maximum summer temperatures).

The duration of the trial was 13 months, during which the crop completed two production cycles. Since sorghum is a crop with re-sprouting capacity, once the first cycle was completed (210 days after sowing $-\mathrm{D}_{210}$ ), sorghum plants were cut about $2 \mathrm{~cm}$ from the growing substrate surface and re-sprouted to complete a new crop cycle (390 days after sowing $-\mathrm{D}_{390}$ ).

\subsection{Plant Measurements and Substrate Analysis}

After completing both production cycles, all the plants were cut and the following measures were taken:

- Biological yield (by drying in an oven until weight stabilization at $70^{\circ} \mathrm{C}$ ): dry grain weight (when presence), shoot dry weight, and roots dry weight were differentiated. Data related to the root dry weight were only measured in the second harvest, when the trial was completely finished.

- Plants size: height from stem base to insertion point of flag leaf; stem diameter and flag leaf length (when presence).

In addition to the above parameters, growing substrates and leaf analyses were done once the trial was finished. The following parameters were analyzed:

- Growing substrates: primary and selected secondary nutrients, soil organic matter (SOM), cation exchange capacity (CEC-volumetric titration), water holding capacity (WHC). Leaves: elemental $\mathrm{N}$, total P and K.

\subsection{Statistical Analysis of Results}

Final data were statistically analyzed using the IBM SPSS Statistics v.22 (IBM Corp., Armonk, NY, USA) software package by three-way ANOVA, where the effects of factors and their interactions were studied. Two-way ANOVA was conducted as a function of texture substrate when significant differences were detected for this factor. One-way ANOVA was adopted to analyze biochar effects on seed germination. Means comparisons were combined with Tukey's test with a significance level of 0.05. Contingency tables were adopted to analyze grain production. 


\section{Results and Discussion}

\subsection{Biomass and Biochar Properties}

Results from proximate and elemental analyses are summarized in Table 1. As expected, these results were primarily dependent on pyrolysis operating conditions. Results from physicochemical analyses of produced biochars are reported in Table 2, from which it can be concluded that nutrient contents of produced biochars were mainly affected by the biomass feedstock.

Table 1. Proximate and elemental analyses of biochar produced at two different temperatures $\left(400{ }^{\circ} \mathrm{C}-\mathrm{B} 400\right.$ and $\left.600{ }^{\circ} \mathrm{C}-\mathrm{B} 600\right)$.

\begin{tabular}{|c|c|c|c|c|c|}
\hline \multicolumn{3}{|c|}{ Proximate } & \multicolumn{3}{|c|}{ Elemental (wt. $\%$ in daf ${ }^{1}$ Basis) ${ }^{2}$} \\
\hline & B400 & B600 & & B400 & B600 \\
\hline Ash (wt. \% in dry basis) & $6.45 \pm 0.14$ & $10.02 \pm 0.81$ & $\begin{array}{l}\mathrm{C} \\
\mathrm{H}\end{array}$ & $\begin{array}{c}71.50 \pm 0.48 \\
4.46 \pm 0.19\end{array}$ & $\begin{array}{c}82.89 \pm 0.33 \\
1.95 \pm 0.08\end{array}$ \\
\hline Moisture (wt. \%) & $0.57 \pm 0.22$ & $3.05 \pm 0.34$ & $\begin{array}{l}\mathrm{N} \\
\mathrm{O}\end{array}$ & $\begin{array}{c}1.58 \pm 0.10 \\
22.42 \pm 0.77\end{array}$ & $\begin{array}{c}1.52 \pm 0.01 \\
13.63 \pm 0.31\end{array}$ \\
\hline $\begin{array}{c}\text { Volatile matter (wt. \% in } \\
\text { dry basis) }\end{array}$ & $22.03 \pm 0.01$ & $2.39 \pm 0.71$ & $\begin{array}{r}\text { Surface } \\
\mathrm{S}_{\text {bet }}\left(\mathrm{m}^{2} \mathrm{~g}^{-1}\right)\end{array}$ & $\begin{array}{c}\text { ea and pore v } \\
105.8\end{array}$ & $\begin{array}{l}\text { lume } \\
227.5\end{array}$ \\
\hline $\begin{array}{c}\text { Fixed carbon (wt. \% in dry } \\
\text { basis) }\end{array}$ & $70.88 \pm 6.45$ & $84.54 \pm 1.32$ & $\begin{array}{l}\mathrm{V}_{\text {total }}\left(\mathrm{cm}^{3} \mathrm{~g}^{-1}\right) \\
\mathrm{V}_{\text {ultra }}\left(\mathrm{cm}^{3} \mathrm{~g}^{-1}\right)\end{array}$ & $\begin{array}{l}0.0370 \\
0.0361\end{array}$ & $\begin{array}{l}0.0819 \\
0.0816\end{array}$ \\
\hline
\end{tabular}

${ }^{1}$ Dry-ash-free. ${ }^{2}$ Oxygen is calculated by difference.

Table 2. Physicochemical analyses of biochar produced at two different temperatures $\left(400^{\circ} \mathrm{C}-\mathrm{B} 400\right.$ and $\left.600{ }^{\circ} \mathrm{C}-\mathrm{B} 600\right)$.

\begin{tabular}{|c|c|c|c|c|c|c|c|c|c|}
\hline \multicolumn{10}{|c|}{ Physicochemical Analyses (Organic Amendment Reference) } \\
\hline \multirow{2}{*}{$\begin{array}{l}\text { Principal } \\
\text { Nutrients }\end{array}$} & \multirow{2}{*}{ Method } & \multirow{2}{*}{ Unit } & \multicolumn{2}{|c|}{ Result } & \multirow{2}{*}{$\begin{array}{l}\text { Secondary } \\
\text { Nutrients }\end{array}$} & \multirow{2}{*}{ Method } & \multirow{2}{*}{ Unit } & \multicolumn{2}{|c|}{ Result } \\
\hline & & & B400 & B600 & & & & B400 & B 600 \\
\hline $\mathrm{N}_{\text {total }}$ Kjeldahl & MT-FER-001 & wt $\%$ & 1.40 & 1.20 & $\mathrm{Ca}_{\text {total }}(\mathrm{CaO})$ & ICP-OES & wt $\%$ & 2.90 & 3.80 \\
\hline $\mathrm{P}_{\text {total }}\left(\mathrm{P}_{2} \mathrm{O}_{5}\right)$ & VISIB. ULTR. & wt $\%$ & 2.08 & 2.45 & $\mathrm{Mg}_{\text {total }}(\mathrm{MgO})$ & ICP-OES & wt $\%$ & 0.68 & 0.79 \\
\hline $\mathrm{K}_{\text {total }}\left(\mathrm{K}_{2} \mathrm{O}\right)$ & ICP-OES & wt $\%$ & 1.70 & 2.10 & $\mathrm{Na}$ total $\left(\mathrm{Na}_{2} \mathrm{O}\right)$ & ICP-OES & $\mathrm{mg} \mathrm{kg}^{-1}$ & 850.00 & 540.00 \\
\hline \multirow{2}{*}{ Microel. } & \multirow{2}{*}{ Method } & \multirow{2}{*}{ Unit } & \multicolumn{2}{|c|}{ Result } & \multirow{2}{*}{ Phys-Chem } & \multirow{2}{*}{ Method } & \multirow{2}{*}{ Unit } & \multicolumn{2}{|c|}{ Result } \\
\hline & & & B400 & B600 & & & & B400 & B600 \\
\hline $\mathrm{Fe}_{\text {total }}$ & ICP-OES & $\mathrm{mg} \mathrm{kg}^{-1}$ & 280 & 210 & $\mathrm{SOM}^{1}$ & Calcin. & wt $\%$ & 86.40 & 85.40 \\
\hline Co total & ICP-OES & $\mathrm{mg} \mathrm{kg}^{-1}$ & 43 & 38 & Apparent density & \multicolumn{2}{|c|}{$\mathrm{g}\left(\mathrm{cm}^{3}\right)^{-1}$} & 0.33 & 0.40 \\
\hline Mn total & ICP-OES & $\mathrm{mg} \mathrm{kg}^{-1}$ & 100 & 102 & $\mathrm{WHC}^{2}$ & Gravim. & $\mathrm{v} \%$ & 14.16 & 18.35 \\
\hline $\mathrm{Zn}$ total & ICP-OES & $\mathrm{mg} \mathrm{kg}^{-1}$ & 145 & 135 & $\mathrm{pH}(1: 2.5)$ & Potenc. & & 8.6 & 8.57 \\
\hline
\end{tabular}

${ }^{1}$ Soil Organic Matter. ${ }^{2}$ Water holding capacity.

B600 had a higher fixed carbon and ash compared to B400, which conversely had a higher amount of volatile matter. The hydrogen, nitrogen, and oxygen fractions decreased with increasing pyrolysis final temperature. Both specific surface area $\left(S_{\text {bet }}\right)$ and pore volume increased with rising pyrolysis final temperature, as a result of the removal of $\mathrm{H}$ and $\mathrm{O}$ during the enhanced devolatilization process, which resulted in more developed pore structures. The total pore volume increased with pyrolysis peak temperature.

Physicochemical analyses were carried out in the same way as any other organic amendment, in order to quantify the levels of available nutrients. Principal and secondary nutrient levels showed no major differences between B400 and B600 that would justify different application rates for the same crop.

It was interesting to analyze total $\mathrm{N}$ content in biochars, also taking into account the ammonia fraction instead of just the organic N. However, the biochar's resistance against digestion with acids should be considered when analytical methods, such as total $\mathrm{N}$ Kjeldhal, are applied [9]. This explains 
the results reported in Table 2 for $\mathrm{N}$ total Kjeldhal, which are slightly lower than those reported in Table 1 for organic $\mathrm{N}$ from elemental analyses.

WHC was found to increase with increasing pyrolysis final temperature. Both B400 and B600 showed higher values of WHC than those measured for the initially selected soils (see Table S1).

Particle size distributions of biochars after the mechanical agitation process are listed in Table 3.

Table 3. Average particle size distribution after mechanical biochar processing with automatic remover for the two pyrolysis temperatures $\left(400{ }^{\circ} \mathrm{C}-\mathrm{B} 400\right.$ and $\left.600{ }^{\circ} \mathrm{C}-\mathrm{B} 600\right)$.

\begin{tabular}{ccc}
\hline Fraction & B400 (wt. \%) & B600 (wt. \%) \\
\hline$<2 \mathrm{~mm}$ & 7 & 4 \\
$2 \mathrm{~mm}<\mathrm{x}<20 \mathrm{~mm}$ & 24 & 19 \\
$20 \mathrm{~mm}<\mathrm{x}<40 \mathrm{~mm}$ & 43 & 55 \\
$\geq 40 \mathrm{~mm}$ & 26 & 22 \\
\hline
\end{tabular}

The obtained mass fraction for particle sizes below $2 \mathrm{~mm}$ was very low. In addition, $69-77 \%$ of the biochar applied in this work was in the form of particle sizes ranging from $20 \mathrm{~mm}$ to more than $40 \mathrm{~mm}$. Smaller particle sizes are usually adopted in most experiments in which the influence of this parameter is evaluated $[50,52]$. However, it is necessary to reach a trade-off concerning the most appropriate particle size, since grinding the biomass feedstock before pyrolysis is an energy-intense pretreatment and grinding biochar could lead to an excessive production of powder-like particles, which are difficult to apply into soil.

Results from proximate, elemental, ash analysis, and biomass components of vine shoots are summarized in Table S2.

Table S3 reports the biochar mass yields from pyrolysis experiments. As expected, the biochar average mass yield $\left(\mathrm{y}_{\text {char }}\right)$ notably decreased when the pyrolysis final temperature increased $\left(\mathrm{B} 400-\mathrm{y}_{\text {char }}=0.38\right.$ and $\left.\mathrm{B} 600-\mathrm{y}_{\text {char }}=0.29\right)$.

\subsection{Phytotoxicity Test}

The germination index (GI) is an integrative measure of compounds of low toxicity (affecting root growth) and high toxicity (affecting germination) [50]. Table 4 shows the main GI values and standard deviation for the selected species. One-way analysis of variance evaluating the effect of biochar temperature on GI for this species did not detect significant differences $(p=0.182)$ between treatments. However, in agreement with Zucconi et al. [49], GI values between 50\%-80\% represent moderate phytotoxicity. These low values were only observed for high-temperature biochars $\left(600^{\circ} \mathrm{C}\right)$ for both watercress and lettuce. On the other hand, GI values above 100 reveal phytostimulant effects of the tested solution. A slightly higher value was found in basil results under B400 treatment, and an apparent phytostimulant effect for B400 was detected in lettuce. Values between $80 \%-100 \%$ denote a lack of phytotoxicity. Therefore, no adverse effects of biochar were found on sorghum germination through this type of phytotoxicity test. According to Busch et al. [53], high ash content in biochar can cause negative effects due to saline stress. It could explain some of the effects in the smaller seeds (watercress, lettuce and basil) which showed greater sensitivity to the B600 extract than the larger seeds. Biochar could still be able to affect seeds germination through other ways like direct contact or volatiles emission [54]; however, the evaluation of these alternative ways is out of the scope of the present paper. 
Table 4. Germination index and standard deviation for different species and two pyrolysis temperatures of biochar $\left(400^{\circ} \mathrm{C}-\mathrm{B} 400\right.$ and $\left.600{ }^{\circ} \mathrm{C}-\mathrm{B} 600\right)$.

\begin{tabular}{ccc}
\hline Specie & B400 & B600 \\
\hline Watercress & $92 \pm 6$ & $71 \pm 5$ \\
Barley & $89 \pm 8$ & $95 \pm 8$ \\
Lettuce & $111 \pm 8$ & $75 \pm 8$ \\
Basil & $102 \pm 12$ & $99 \pm 9$ \\
Sorghum & $85 \pm 7$ & $98 \pm 5$ \\
\hline
\end{tabular}

From the results obtained from a phytotoxicity test, it can be concluded that a preliminary washing step of biochar with water is not absolutely required. In other words, for the pyrolysis operating conditions adopted in this study, the organic compounds available on biochar surface did not inhibit germination of selected seeds.

\subsection{Crop Response}

\subsubsection{First Crop Development Cycle}

Results of the three-way ANOVA concerning the effect of growing substrate type, pyrolysis final temperature, and application rate on the growth parameters did not show statistically significant differences for the first crop cycle $(p>0.05)$. All the plants produced grain and no differences were observed for the total biomass generated. It should be pointed out, however, that we were unable to measure the root dry weights at this stage, since plants were re-sprouted to complete a new cycle.

Differences in crop growth and yield were reported in other studies when biochar was applied in short-term experiments [32,38,44,45]. Other studies based on biochar application on sorghum crop showed clear effects on crop growth under short-term trials [44]; in addition, vine-shoots derived biochar had an influence when it was applied to growing different crops in many studies [38]. In this sense, we have to emphasize that the larger biochar particles used here, in conjunction with the calcareous-like growing substrates, could limit biochar effects on this first crop stage. Furthermore, and according to Igalavithana et al. [24], for soils with organic matter and plant-available nutrients, the potential capacity of biochar to supply nutrients could not be ruled out. In this sense, nutrient deficiency symptoms observed in our experiment forced us to water the plants with a nutritive solution, which provided easily available nutrients for plants and which could mask the possible effect of supplying nutrients by biochar addition.

The main values and standard deviation of principal productive parameters measured at the final of the first completed crop cycle $\left(\mathrm{D}_{210}\right)$ are summarized in Table S4.

\subsubsection{Second Crop Development Cycle}

The results of the three-way ANOVA of plant dry weight data at the end of the second crop development cycle are shown in Table 5. Soil texture was the main factor that significantly affected the studied variables. At the same time, a significant influence of the biochar temperature and application rate on root weight was also observed. An additional effect of the application rate on plants' total weight, shoot weight, and root weight was also detected (see Figure 1). 
Table 5. Three-way ANOVA results of the effect of growing substrate texture, biochar temperature and application rate on biomass dry weight of sorghum crop in pots experiment.

\begin{tabular}{cccccc}
\hline Factor & $\mathbf{d f}$ & $\mathbf{W}_{\mathbf{T}}$ & $\mathbf{W}_{\mathbf{S}}$ & $\mathbf{W}_{\mathbf{G}}$ & $\mathbf{W}_{\mathbf{R}}$ \\
\hline Growing substrate texture (S) & 1 & $* * *$ & $* * *$ & $\mathrm{~ns}$ & $*$ \\
Biochar temperature (B) & 1 & $\mathrm{~ns}$ & $\mathrm{~ns}$ & $\mathrm{~ns}$ & $*$ \\
Application rate (D) & 1 & $*$ & $*$ & $\mathrm{~ns}$ & $*$ \\
S $\times$ B & 1 & $\mathrm{~ns}$ & $\mathrm{~ns}$ & $\mathrm{~ns}$ & $*$ \\
S $\times \mathrm{D}$ & 1 & $\mathrm{~ns}$ & $\mathrm{~ns}$ & $\mathrm{~ns}$ & $\mathrm{~ns}$ \\
B $\times \mathrm{D}$ & 1 & $\mathrm{~ns}$ & $\mathrm{~ns}$ & $\mathrm{~ns}$ & $\mathrm{~ns}$ \\
$\mathrm{~S} \times \mathrm{B} \times \mathrm{D}$ & 1 & $\mathrm{~ns}$ & $\mathrm{~ns}$ & $\mathrm{~ns}$ & $\mathrm{~ns}$
\end{tabular}

$* p \leq 0.05$ : $\overline{* * *} p \leq 0.001$; and $\mathrm{ns}=$ not significantly different. $\mathrm{W}_{\mathrm{T}}$ : total dry weight; $\mathrm{W}_{\mathrm{S}}$ : shoot dry weight; $\mathrm{W}_{\mathrm{G}}$ : grain dry weight; $\mathrm{W}_{\mathrm{R}}$ : root dry weight.

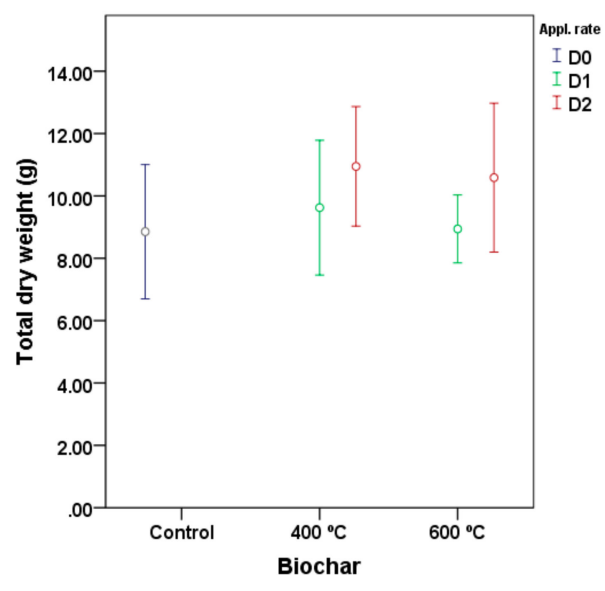

(a)

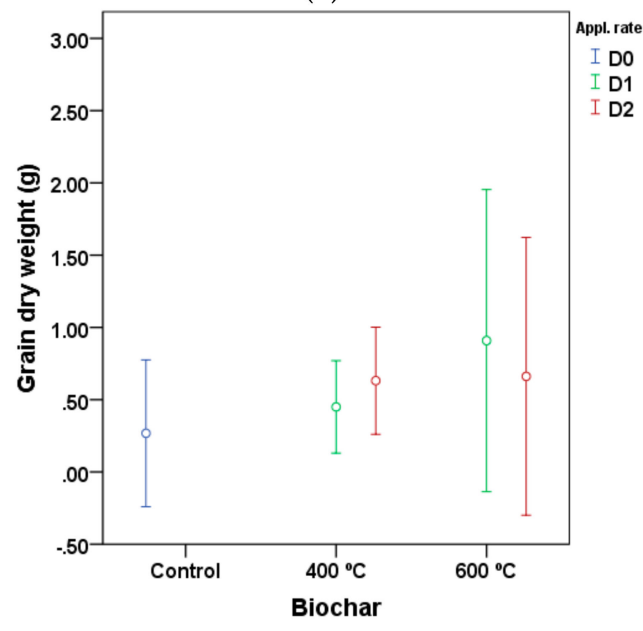

(c)

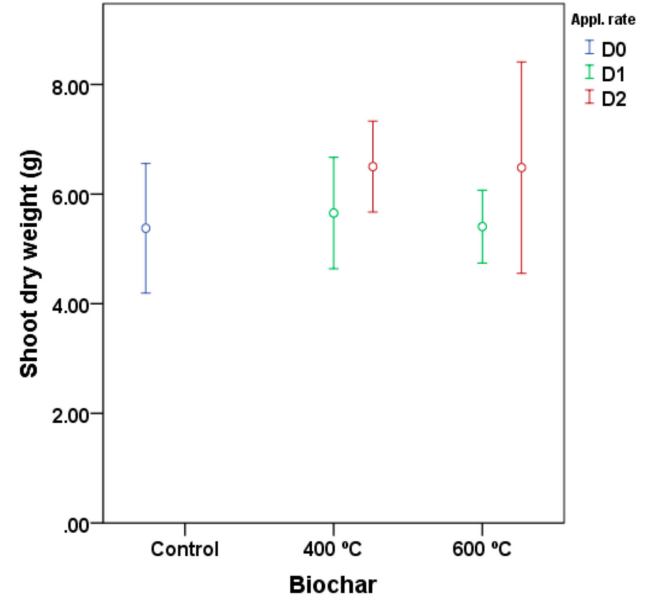

(b)

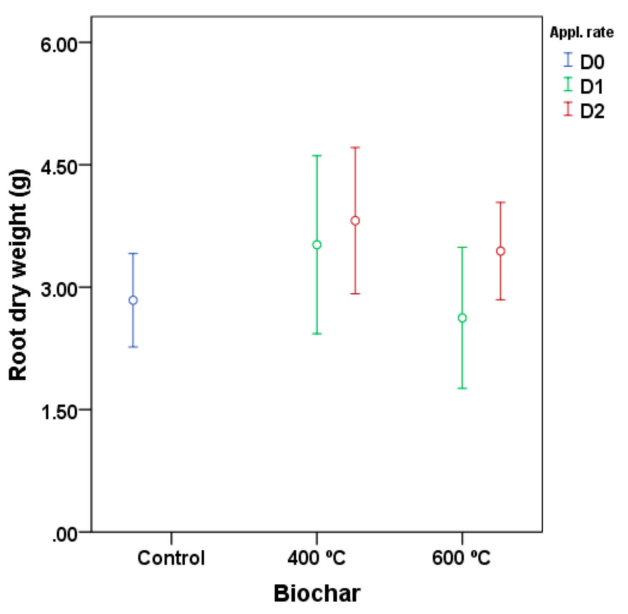

(d)

Figure 1. Main value and confidence interval at $95 \%$ of biomass dry weight on the second cycle of a sorghum crop under different application rates (0 wt. \%-D0; $1.5 \mathrm{wt}$. \%—D1; $3 \mathrm{wt}$. \%-D2) of biochar at $400{ }^{\circ} \mathrm{C}$ and $600{ }^{\circ} \mathrm{C}$. (a) total dry weight, (b) shoot dry weight, (c) grain dry weight, (d) root dry weight; average values between the sandy-loam growing substrate (S1) and the clay-loam growing substrate (S2).

The results of two-way ANOVA for different soil textures showed significant differences $(p<0.05)$ in root dry weight when sorghum - were growing in the sandy-loam substrate (S1) with the addition of the biochar produced at $400{ }^{\circ} \mathrm{C}$ (regardless of the application rate). These differences were found 
between B400 and B600 treatments $(p<0.0001)$ and between B400 and Control treatments $(p=0.002)$. Root dry weight in B400 treatment increased by 52\% compared to the Control treatment and by $57 \%$ compared to B600. This analysis did not show significant differences in the clay-loam growing substrate (S2). The main values of root dry weight in S1 are shown in Figure 2.

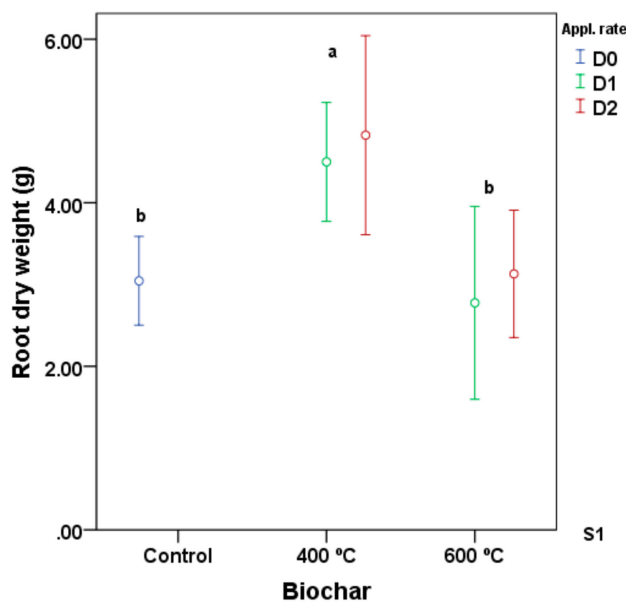

(a)

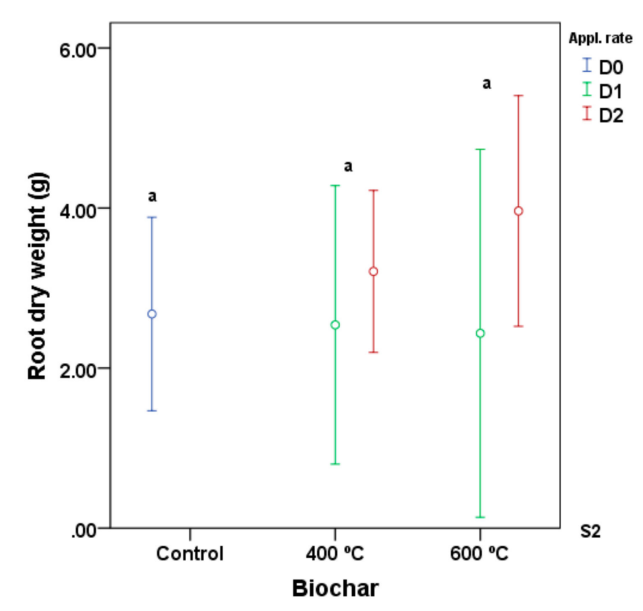

(b)

Figure 2. Main value and confidence interval at $95 \%$ of root dry weight on the second cycle of a sorghum crop under different application rates of biochar at $400{ }^{\circ} \mathrm{C}$ and $600{ }^{\circ} \mathrm{C}$ (a) total root dry weight in the growing substrate with the sandy-loam component-S1, (b) total root dry weight in clay-loam-S2. Different letters indicate significant differences $(p<0.05$; Tukey's test).

Although no significant differences were found for grain dry weight, not all of the plants produced grain yield in this second harvest. Contingency tables showed a statistically significant relationship (Table 6) between the grain production and the three factors selected for this study. Based on these results, biochar produced at $400{ }^{\circ} \mathrm{C}$ could enhance crop productivity in sandy-loam soils.

Table 6. Summarized contingency tables for sorghum plants grain production (\% plants) under different treatments (growing substrate S1: sandy-loam; growing substrate S2: clay-loam; B400—Biochar $400{ }^{\circ} \mathrm{C}$; B600-biochar $600{ }^{\circ} \mathrm{C}$; app. rate D1-1.5 wt. \%; app. rate D2-3 wt. \%).

\begin{tabular}{ccccccccc}
\hline \multirow{2}{*}{ Grain Production } & \multicolumn{2}{c}{ Growing Substrate } & \multicolumn{3}{c}{ Biochar } & \multicolumn{3}{c}{ Application Rate } \\
\cline { 2 - 9 } & S1 & S2 & Control & B400 & B600 & D1 & D2 \\
\hline Yes & 86 & 57 & 22 & 88 & 65 & 76 & 25 \\
No & 14 & 43 & 78 & 12 & 35 & 24 & 75 \\
$\chi^{2}$ & & & 0.004 & & & 0.005 & & \multicolumn{2}{c}{0.012} \\
\hline
\end{tabular}

In agreement with earlier results reported by Khaled and Schoenau [55] and Laghari et al. [44], the application of biochar produced at low temperature (B400) leads to higher biological yield compared to the control treatment and biochar produced at higher temperatures (B600) in a sandy-loam growing substrate. Olmo et al. [56], who worked with olive-tree pruning-derived biochar, found significant differences for biochar application in root morphology as a result of the effect on some nutrient availability and the subsequent fine root proliferation. Butnan et al. [26] reported that lower final temperatures of biochar $\left(350{ }^{\circ} \mathrm{C}\right)$ showed higher benefits on crop development than the higher temperatures $\left(800{ }^{\circ} \mathrm{C}\right)$ in two textured soils. Gale and Thomas [32] recently reported a high dose-dependence of biomass and physiological traits response. These works related crop yield enhancement to increased nutrient uptake. However, in the present study, there was no clear increase in nutrient uptake, as explained in the next section. According to these results, root morphology could be a parameter for assessing, since the study of root morphology would complement conclusions both 
for physicochemical analyses and biological response in growing substrates. A not yet published study of root mycorrhization by arbuscular mycorrhizal fungi (AMF) in this experiment will complement the information reported in this study, in which AMF colonization was increased with B400 application. This parameter was highly correlated with root dry weight.

\subsection{Growing Substrates Changes and Leaves' Nutrient Contents}

A significant increase in WHC was observed by the addition of biochar $(p<0.05$ between Control treatment and biochar amendment); the increase in WHC was observed for both studied substrates textures. There was also a significant influence of thepyrolysis final temperature on water retention, which increased by 3-6\% with biochar temperature ( $p \leq 0.05$ between B600 and B400; $p \leq 0.05$ between biochars and control treatment without biochar). Only in clay-loam substrate, WHC increased significantly $(p \leq 0.001)$ with application rate. This behavior was also reported by Ali et al. [57] using biochar application rates of 25 and $50 \mathrm{Mg} \mathrm{ha}^{-1}$ of biochar. Figure 3 illustrates the behavior of each type of growing substrate. Numerous studies have demonstrated that biochar amendment improves WHC [3,57,58]; the present study reports a direct relationship between WHC and pyrolysis final temperature, which is directly correlated with WHC values already measured for individual biochar analyses (see Table 2). In agreement with Marshall et al. [39], who also reported a high hydrophobicity in vine shoots-derived biochar produced at $400{ }^{\circ} \mathrm{C}$, it could be an important parameter to take into account, and not only the macroporous structure of biochar which could led to attribute higher WHC at lower pyrolysis peak temperatures. Accordingly, the dependence of this parameter on pyrolysis temperature is an aspect that could be of interest for agronomic contributions.

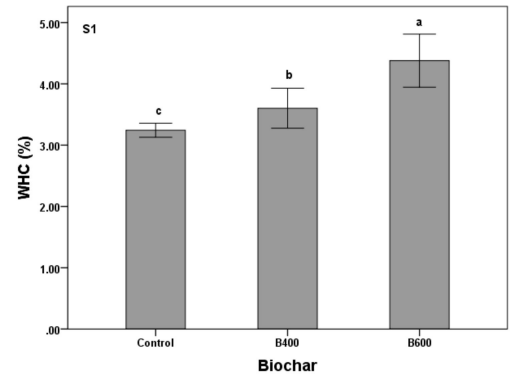

(a)

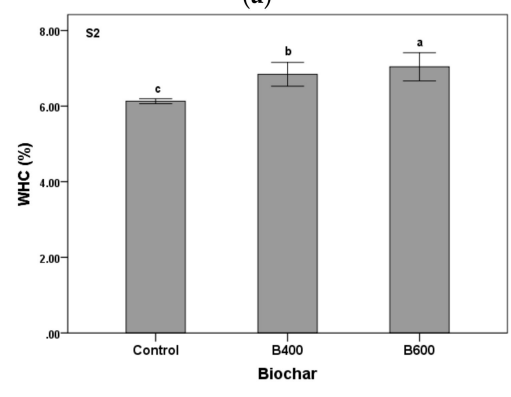

(c)

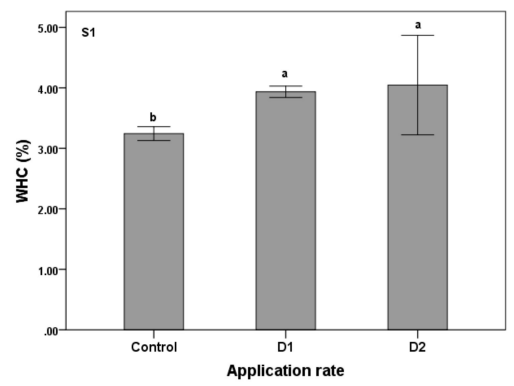

(b)

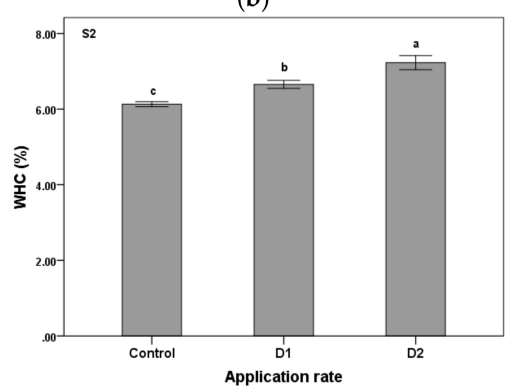

(d)

Figure 3. Main value and confidence interval at $95 \%$ of substrates water holding capacity (WHC) in two different texture of growing substrates, temperature of biochar applied $\left(400{ }^{\circ} \mathrm{C}-\mathrm{B} 400\right.$ and $\left.600{ }^{\circ} \mathrm{C}-\mathrm{B} 600\right)$ and application rate (D1: $1.5 \mathrm{wt}$. \%; D2: $3 \mathrm{wt}$ \%). (a) effect of final pyrolysis temperature of biochar applied on WHC in substrate with sandy-loam component-S1, (b) effect of biochar application rate on WHC in substrate with sandy-loam component-S1, (c) effect of final pyrolysis temperature of biochar applied on WHC in substrate with clay-loam component-S2, (d) effect of biochar application rate on WHC in substrate with clay-loam component-S2. Different letters indicate significant differences $(p<0.05 ;$ Tukey's test). 
Differences in nutrient concentrations in growing media and leaves are deduced from Table 7. In the present experiment, biochar application had a significant influence $(\mathrm{p}<0.05)$ on $\mathrm{pH}$ in the sandy-loam substrate, decreasing values over 0.1 points. The obtained results are in agreement with those by Liu and Zhang [59], who reported that biochar application decreased growing media $\mathrm{pH}$ in a sandy-loam texture. In their study, $\mathrm{pH}$ reduction was enhanced with an increasing biochar application rate and incubation time, related to the production of acidic materials from biochar oxidation.

Table 7. Nutrient concentrations in growing media and sorghum leaves, and water holding capacity (WHC) with different pyrolysis temperatures of biochar $\left(400{ }^{\circ} \mathrm{C}-\mathrm{B} 400\right.$ and $600{ }^{\circ} \mathrm{C}-\mathrm{B} 600$; S1: sandy-loam growing substrate; S2: clay-loam growing substrate).

\begin{tabular}{|c|c|c|c|c|c|c|}
\hline \multirow{2}{*}{ Variable } & \multicolumn{3}{|c|}{ S1 } & \multicolumn{3}{|c|}{ S2 } \\
\hline & Control & B400 & B600 & Control & B400 & B600 \\
\hline $\mathrm{pH}$ & $8.43 \pm 0.14 \mathrm{a}^{2}$ & $8.33 \pm 0.15 \mathrm{ab}$ & $8.27 \pm 0.06 b$ & $\mathrm{~ns}^{3}$ & $\mathrm{~ns}$ & ns \\
\hline $\mathrm{K}\left(\mathrm{mg} \mathrm{kg}^{-1}\right)$ & $297.0 \pm 31.0 \mathrm{~b}$ & $305 \pm 8.9 b$ & $358.5 \pm 18.7 \mathrm{a}$ & $267.0 \pm 51.0 \mathrm{c}$ & $369.8 \pm 26.7 b$ & $448.5 \pm 61.6 \mathrm{a}$ \\
\hline $\mathrm{Mg}\left(\mathrm{mg} \mathrm{kg}^{-1}\right)$ & ns & ns & ns & $329.0 \pm 3.0 \mathrm{~b}$ & $371.2 \pm 16.5 \mathrm{a}$ & $371.5 \pm 21.9 \mathrm{a}$ \\
\hline $\mathrm{Ca}\left(\mathrm{mg} \mathrm{kg}^{-1}\right)$ & $4329.0 \pm 253.0 \mathrm{a}$ & $3860.0 \pm 142.5 b$ & $4191.2 \pm 253.3 \mathrm{a}$ & $6088.0 \pm 123.0 \mathrm{~b}$ & $6154.3 \pm 173.2 \mathrm{a}$ & $5779.5 \pm 281.7 b$ \\
\hline $\mathrm{K} / \mathrm{Ca}$ & $0.068 \pm 0.004 c$ & $0.079 \pm 0.003 \mathrm{~b}$ & $0.086 \pm 0.004 \mathrm{a}$ & $0.044 \pm 0.009 c$ & $0.060 \pm 0.005 b$ & $0.078 \pm 0.014 \mathrm{a}$ \\
\hline $\mathrm{K} / \mathrm{Mg}$ & $1.338 \pm 0.058 \mathrm{~b}$ & $1.373 \pm 0.036 \mathrm{~b}$ & $1.519 \pm 0.036 \mathrm{a}$ & $0.811 \pm 0.150 \mathrm{c}$ & $0.996 \pm 0.034 \mathrm{~b}$ & $1.205 \pm 0.124 \mathrm{a}$ \\
\hline K-leaf & ns & ns & ns & $2.1 \pm 0.2 b$ & $2.4 \pm 0.2 \mathrm{a}$ & $2.3 \pm 0.2 \mathrm{a}$ \\
\hline $\mathrm{WHC}^{1}(\%)$ & $3.24 \pm 0.04 c$ & $3.60 \pm 0.32 b$ & $4.37 \pm 0.41 \mathrm{a}$ & $6.13 \pm 0.03 c$ & $6.84 \pm 0.30 b$ & $7.04 \pm 0.35 \mathrm{a}$ \\
\hline
\end{tabular}

${ }^{1}$ WHC: Water Holding Capacity. ${ }^{2}$ For the same kind of growing substrate, means followed by different letter (within a row) are significantly different at $p<0.05$ (Tukey's test). ${ }^{3} \mathrm{~ns}=$ not significantly different at $p<0.05$.

No differences were observed in total SOM or CEC between treatments (Tables S5 and S6). It could be explained by the large particle size of biochar adopted in this experiment. In this sense, when substrates' chemical analyses were carried out, particles of biochar were considered thick elements, and were separated from the analytical samples; the fine fraction able of interacting with clay and organic matter in the soil represented $4-7 \%$ of the total amount of biochar applied, which is a small addition to influence soil parameters.

Complete nutrient concentration data are given in Tables S5 and S6.

In contrast to other studies $[14,43,46]$, the three-way ANOVA showed that the application of biochar did not significantly modify the cation exchange capacity, soil organic matter, total nitrogen concentration, and available phosphorus concentration. Significant differences $(p<0.05)$ were found for both types of textures in $\mathrm{K}$ and $\mathrm{Ca}$ concentrations. The content of available $\mathrm{K}$ was significantly related to the texture of the substrate $(p<0.0001)$. In addition, there was a positive interaction between texture growing media and application rate $(p=0.006)$, and between biochar and application rate $(p=0.037)$. Two-way ANOVA for a given texture showed that significant differences $(p<0.05)$ on $\mathrm{K}$ concentration in $\mathrm{S} 1$ are related to $\mathrm{B} 600$ addition but not to application rate. S2 showed significant differences $(p<0.05)$ for biochar addition and application rate in this texture. B600 application at $3 \mathrm{wt}$. $\%$ improved soil $\mathrm{K}$ content by $67 \%$ in comparison with control treatment (see Figure 4). 


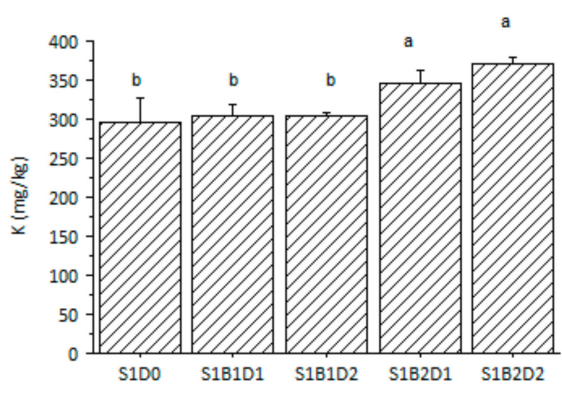

(a)

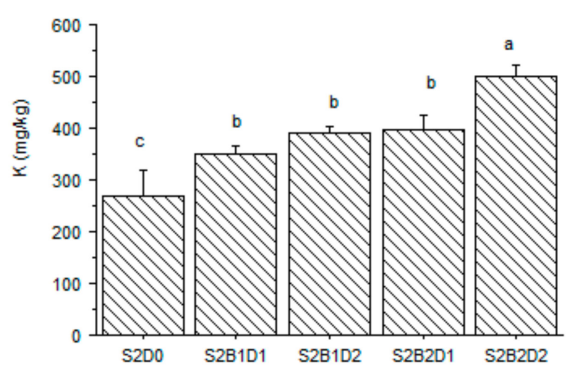

(b)

Figure 4. Main value and standard deviation of $\mathrm{K}$ concentration in two different growing media with a different application rate of biochar. (a) K concentration in the sandy-loam growing substrate-S1, (b) K concentration in the clay-loam substrate-S2; B1: biochar produced at $400{ }^{\circ} \mathrm{C}$; B2: biochar produced at $600{ }^{\circ} \mathrm{C}$; D1: $1.5 \mathrm{wt}$ \%; D2: $\left.3 \mathrm{wt} . \%\right)$. Different letters indicate significant differences $(p<0.05$; Tukey's test).

K concentration in leaves also showed significant differences $(p<0.005)$ related to biochar application.

Positive interactions were found between the effect of texture growing media and biochar $(p<0.0001)$ and between texture and application rate $(p=0.035)$ on Ca concentrations. Analyzing each textural type individually, it was observed that significant differences $(p \leq 0.05)$ in Ca concentration in $\mathrm{S} 1$ were related to $\mathrm{B} 600$ applied at the higher rate ( $3 \mathrm{wt}$. \%). Different behavior was observed in S2, where significant differences $(p \leq 0.05)$ in Ca concentration were observed for B400 application.

Biochar addition at higher doses had significant effects $(p<0.0001)$ on $\mathrm{Mg}$ concentration only in the clay-loam growing substrate, regardless of the pyrolysis final temperature $(p=0.950)$.

In both substrates, the K/Ca ratio used resulted in being extremely low because of the elevated Ca content, indicating the high difficulty of $\mathrm{K}$ absorption by plants. In general, this ratio ranges between $2-10$, and the values obtained in this study vary from 0.044 to 0.089 .

Significant differences were observed for this ratio between growing substrates $(p<0.0001)$, also between biochar temperatures $(p<0.0001)$ and between application rate $(p=0.0002)$. Biochar addition increases $\mathrm{K} / \mathrm{Ca}$ for both textures of growing media in comparison with control treatment $(p<0.05)$, and $\mathrm{K} / \mathrm{Ca}$ increases with application rate only in the clay-loam growing substrate $(p<0.05)$.

Another cation ratio related to soil and crop fertility is $\mathrm{K} / \mathrm{Mg}$. This ratio followed the same trend observed for the previous one. Three-way ANOVA showed significant differences derived from biochar application in both textures $(p<0.0001)$ except the application of B400 at lower doses in the sandy-loam substrate compared to control treatment, where no differences were detected. Otherwise, analyzing the effects in the clay-loam growing substrate treatments, an evident increment in $\mathrm{K} / \mathrm{Mg}$, was observed when both pyrolysis temperature and application rate were increased $(p=0.0008$ between B2 and B1; $p=0.025$ between $\mathrm{S} 2$ and S1).

According to earlier studies [54,59-61], biochar application has an evident influence on essential macronutrients' availability. Significant differences have been reported in this experiment for $\mathrm{K}, \mathrm{Ca}, \mathrm{Mg}$, and their ratios. Incorporation of biochar as a soil amendment stimulates plant growth by increasing the availability of essential nutrients [22]. However, a nutritive solution was necessarily adopted in this experiment to maintain plants development and to supply nutrient deficiencies shown by the crop. Complementary field-scale experiments, where plants growth is not limited by pot dimensions and growing substrate mixture, are needed to confirm the results reported in this study.

\section{Conclusions}

Vine shoots represent an interesting resource for biochar production, due to their relative easily handling and slow pyrolysis processing, and the most important aspect, the appropriate physicochemical properties of resulting biochars. A moderate risk of phytotoxicity effects on seed 
germination was determined (just one of the tested species exhibited low GI values for biochar produced at $600^{\circ} \mathrm{C}$ ). The effects of biochar application as an organic amendment, on these experimental conditions, were clearly dependent on the texture of the growing media analyzed. The highest effect on root development was found for the sandy-loam texture with biochar produced at $400{ }^{\circ} \mathrm{C}$, regardless of the application rate. The physicochemical properties of substrates were more severely affected when the highest-temperature biochar was applied. However, further research should be required to optimize the particle size range and application rate of biochar, since an increasing trend in crop development was observed for both texture types when biochar was added at the highest addition rate.

Supplementary Materials: The following are available online at http://www.mdpi.com/2073-4395/10/1/104/s1, Figure S1: Scheme of the automatic remover used to process the biochar, Figure S2: Nutrients concentration, soil organic matter (MOT) and CEC (CICT) deviation of experimental treatments, under different temperatures of biochar and application rate, from control treatment in sandy-loam growing substrate, Figure S3: Nutrients concentration, soil organic matter (MOT) and CEC (CICT) deviation of experimental treatments, under different temperatures of biochar and application rate, from control treatment in clay-loam growing substrate, Table S1: Fertility analyses results of soils collected for the trial, Table S2: Proximate, elemental, X-Ray Fluorescence (XRF) analysis and biomass components of vine shoots, Table S3: Average value of pyrolysis product yield under two different temperature conditions, Table S4: Results from productive parameters at the final of the first completed sorghum cycle ${ }^{1}$ under different biochar and application rates, Table S5: Nutrient concentrations both in sorghum leaves and growing media with different pyrolysis temperatures of biochar added, Table S6: Nutrient concentrations in sorghum leaves and growing substrate with different application rates of biochar.

Author Contributions: Conceptualization, F.J.G.-R. and J.J.M.-C.; Methodology, M.d.C.J.-V., J.J.M.-C., F.J.G.-R., P.M.-M., C.M.-D., and M.V.-M.; validation, F.J.G.-R. and M.V.-M.; formal analysis, M.V.-M., F.J.G.-R., J.J.M.-C., and C.M.-D.; investigation, M.d.C.J.-V., J.J.M.-C., F.J.G.-R., P.M.-M., C.M.-D., and M.V.-M.; resources, M.V.-M.; writing—original draft preparation, M.V.-M.; writing-review and editing, M.d.C.J.-V., J.J.M.-C., F.J.G.-R., P.M.-M., and C.M.-D.; visualization, M.V.-M., F.J.G.-R., and C.M.-D.; supervision, F.J.G.-R., J.J.M.-C., M.d.C.J.-V., P.M.-M., and C.M.-D.; project administration, J.J.M.-C. and M.V.-M.; funding acquisition, F.J.G.-R., J.J.M.-C., and M.V.-M. All authors have read and agreed to the published version of the manuscript.

Funding: This research received funding from the Spanish Ministry of Sciences, Innovation and Universities (ERANET-MED Project MEDWASTE, ref. PCIN-2017-048).

Acknowledgments: The authors would like to acknowledge the collaboration and help given by Manuel Azuara, Gianluca Greco, Christian Di Stasi, Mariano Vidal, Antonio Boné, Jesús Val, Pablo Martín, José Casanova, José Antonio Cuchí, David Badía, Jesús Betrán, José Antonio Manso and laboratory technicians of Technological College of Huesca-Universidad de Zaragoza. Diego Orús, Bodega Sommos, José Luis Orús, Gozde Duman from Ege University (Izmir, Turkey) and Marta Garzón (ICIA, Tenerife).

Conflicts of Interest: The authors declare no conflict of interest.

\section{References}

1. Sanjuán, M.E.; del Barrio, G.; Ruiz, A.; Rojo, L.; Puigdefábregas, J.; Martínez, A. Evaluación de la Desertificación en España: Mapa de la Condición de la Tierra 2000-2010; Ministerio de Agricultura, Alimentación y Medio Ambiente: Madrid, Spain, 2010; p. 80.

2. Chica, A.; Artola, A.; Rosal, A.; Solé-Mauri, F.; Fernandez, F.; García, J.; Dios, M.; Díaz, M.; Ramón, G.; Font, X. De Residuo a Recurso, El camino hacia la Sostenibilidad. In III. Recursos Orgánicos. Aspectos Agronómicos y Mediambientales. Cap. 8: Enmiendas Orgánicas y de Nueva Generación: Biochar y Otras Biomoléculas; Red Española de Compostaje, Ed.; Mundi-Prensa: Madrid, Spain, 2015; p. 290.

3. Guo, M.; He, Z.; Uchimiya, S.M. Introduction to Biochar as an Agricultural and Environmental Amendment. In Agricultural and Environmental Applications of Biochar: Advances and Barriers; Guo, M., He, Z., Uchimiya, S.M., Eds.; Soil Science Society of America, Inc.: Madison, WI, USA, 2016; pp. 1-14.

4. Jeffery, S.; Verheijen, F.G.A.; Velde, M.; Van Der Bastos, A.C. Agriculture, Ecosystems and Environment A quantitative review of the effects of biochar application to soils on crop productivity using meta-analysis. Agric. Ecosyst. Environ. 2011, 144, 175-187. [CrossRef]

5. Paz-Ferreiro, J.; Méndez, A.; Gascó, G.; Guo, M.; He, Z.; Uchimiya, S.M. Application of Biochar for Soil Biological Improvement. In Agricultural and Environmental Applications of Biochar: Advances and Barriers; Guo, M., He, Z., Uchimiya, S.M., Eds.; Soil Science Society of America, Inc.: Madison, MA, USA, 2016; pp. 145-174. 
6. Lal, R. Biochar and Soil Carbon Sequestration. In Agricultural and Environmental Applications of Biochar: Advances and Barriers; Guo, M., He, Z., Uchimiya, S.M., Eds.; Soil Science Society of America, Inc.: Madison, MA, USA, 2016; pp. 175-198.

7. Camps Arbestain, M.; Saggar, S.; Leifeld, J. Environmental benefits and risks of biochar application to soil. Agric. Ecosyst. Environ. 2014, 191, 1-167. [CrossRef]

8. Alburquerque, J.A.; Sánchez, M.E.; Mora, M.; Barrón, V. Slow pyrolysis of relevant biomasses in the Mediterranean basin. Part Char characterisation for carbon sequestration and agricultural uses. J. Clean. Prod. 2016, 120, 191-197. [CrossRef]

9. Steiner, C. Considerations in Biochar Characterization. In Agricultural and Environmental Applications of Biochar: Advances and Barriers; Guo, M., He, Z., Uchimiya, S.M., Eds.; Soil Science Society of America, Inc.: Madison, MA, USA, 2016; pp. 87-100.

10. Herath, H.M.S.K.; Camps-Arbestain, M.; Hedley, M. Effect of biochar on soil physical properties in two contrasting soils: An Alfisol and an Andisol. Geoderma 2013, 209, 188-197. [CrossRef]

11. Jeffery, S.; Meinders, M.B.J.; Stoof, C.R.; Bezemer, T.M.; van de Voorde, T.F.J.; Mommer, L.; van Groenigen, J.W. Biochar application does not improve the soil hydrological function of a sandy soil. Geoderma 2015, 251, 47-54. [CrossRef]

12. Xu, G.; Sun, J.N.; Shao, H.B.; Chang, S.X. Biochar had effects on phosphorus sorption and desorption in three soils with differing acidity. Ecol. Eng. 2014, 62, 54-60. [CrossRef]

13. Arif, M.; Ilyas, M.; Riaz, M.; Ali, K.; Shah, K.; Ul Haq, I.; Fahad, S. Biochar improves phosphorus use efficiency of organic-inorganic fertilizers, maize-wheat productivity and soil quality in a low fertility alkaline soil. Field Crop. Res. 2017, 214, 25-37. [CrossRef]

14. Gul, S.; Whalen, J.K.; Thomas, B.W.; Sachdeva, V.; Deng, H. Physico-chemical properties and microbial responses in biochar-amended soils: Mechanisms and future directions. Agric. Ecosyst. Environ. 2015, 206, 46-59. [CrossRef]

15. Méndez, A.; Terradillos, M.; Gascó, G. Physicochemical and agronomic properties of biochar from sewage sludge pyrolysed at different temperatures. J. Anal. Appl. Pyrolysis 2013, 102, 124-130. [CrossRef]

16. Enders, A.; Hanley, K.; Whitman, T.; Joseph, S.; Lehmann, J. Characterization of biochars to evaluate recalcitrance and agronomic performance. Bioresour. Technol. 2012, 114, 644-653. [CrossRef]

17. Manyà, J.J. Pyrolysis for biochar purposes: A review to establish current knowledge gaps and research needs. Environ. Sci. Technol. 2012, 46, 7939-7954. [CrossRef] [PubMed]

18. Manyà, J.J.; Azuara, M.; Manso, J.A. Biochar production through slow pyrolysis of different biomass materials: Seeking the best operating conditions. Biomass Bioenergy 2018, 117, 115-123. [CrossRef]

19. Zhao, B.; Connor, D.O.; Zhang, J.; Peng, T.; Shen, Z.; Tsang, D.C.W.; Hou, D. Effect of pyrolysis temperature, heating rate, and residence time on rapeseed stem derived biochar. J. Clean. Prod. 2018, 174, 977-987. [CrossRef]

20. Ioannidou, O.; Zabaniotou, A. Agricultural residues as precursors for activated carbon production-A review. Renew. Sustain. Energy Rev. 2007, 11, 1966-2005. [CrossRef]

21. Kavitha, B.; Reddy, P.V.L.; Kim, B.; Lee, S.S.; Pandey, S.K.; Kim, K.H. Benefits and limitations of biochar amendment in agricultural soils: A review. J. Environ. Manag. 2018, 227, 146-154. [CrossRef]

22. Al-Wabel, M.I.; Hussain, Q.; Usman, A.R.A.; Ahmad, M.; Abduljabbar, A.; Sallam, A.S.; Ok, Y.S. Impact of biochar properties on soil conditions and agricultural sustainability: A review. Land Degrad. Dev. 2018, 29, 2124-2161. [CrossRef]

23. Lei, O.; Zhang, R. Effects of biochars derived from different feedstocks and pyrolysis temperatures on soil physical and hydraulic properties. J. Soils Sediments 2013, 13, 1561-1572. [CrossRef]

24. Igalavithana, A.D.; Ok, Y.S.; Usman, A.R.A.; Al-wabel, M.I.; Oleszczuk, P.; Lee, S.S. The Effects of Biochar Amendment on Soil Fertility Could Biochar Be Used as a Fertilizer? In Agricultural and Environmental Applications of Biochar: Advances and Barriers; Guo, M., He, Z., Uchimiya, S.M., Eds.; Soil Science Society of America, Inc.: Madison, MA, USA, 2016; pp. 123-144.

25. Bohara, H.; Dodla, S.; Wang, J.J.; Darapuneni, M.; Acharya, B.S.; Magdi, S.; Pavuluri, K. Influence of poultry litter and biochar on soil water dynamics and nutrient leaching from a very fine sandy loam soil. Soil Tillage Res. 2019, 189, 44-51. [CrossRef] 
26. Butnan, S.; Deenik, J.L.; Toomsan, B.; Antal, M.J.; Vityakon, P. Biochar characteristics and application rates affecting corn growth and properties of soils contrasting in texture and mineralogy. Geoderma 2015, 237, 105-116. [CrossRef]

27. Guo, M. Pyrogenic Carbon in Terra Preta Soils. In Agricultural and Environmental Applications of Biochar: Advances and Barriers; Guo, M., He, Z., Uchimiya, S.M., Eds.; Soil Science Society of America, Inc.: Madison, MA, USA, 2016; pp. 18-28.

28. Bi, Y.; Cai, S.; Wang, Y.; Xia, Y.; Zhao, X.; Wang, S.; Xing, G. Assessing the viability of soil successive straw biochar amendment based on a five-year column trial with six different soils: Views from crop production, carbon sequestration and net ecosystem economic benefits. J. Environ. Manag. 2019, 245, 173-186. [CrossRef]

29. Liu, X.; Zhang, A.; Ji, C.; Joseph, S.; Bian, R.; Li, L.; Pan, G.; Paz-Ferreiro, J. Biochar's effect on crop productivity and the dependence on experimental conditions-A meta-analysis of literature data. Plant Soil 2013, 373, 583-594. [CrossRef]

30. Tanure, M.M.C.; da Costa, L.M.; Huiz, H.A.; Fernandes, R.B.A.; Cecon, P.R.; Pereira Junior, J.D.; da Luz, J.M.R. Soil water retention, physiological characteristics, and growth of maize plants in response to biochar application to soil. Soil Tillage Res. 2019, 192, 164-173. [CrossRef]

31. Laird, D.A.; Fleming, P.; Davis, D.D.; Horton, R.; Wang, B.; Karlen, D.L. Impact of biochar amendments on the quality of a typical Midwestern agricultural soil. Geoderma 2010, 158, 443-449. [CrossRef]

32. Gale, N.V.; Thomas, S.C. Dose-dependence of growth and ecophysiological responses of plants to biochar. Sci. Total Environ. 2019, 658, 1344-1354. [CrossRef] [PubMed]

33. Sun, C.X.; Chen, X.; Cao, M.M.; Li, M.Q.; Zhang, Y.L. Growth and metabolic responses of maize roots to straw biochar application at different rates. Plant Soil 2017, 416, 487-502. [CrossRef]

34. Wrobel-Tobiszewska, A.; Boersma, M.; Sargison, J.; Adams, P.; Singh, B.; Franks, S.; Birch, C.J.; Close, D.C. Nutrient changes in potting mix and Eucalyptus nitens leaf tissue under macadamia biochar amendments. J. For. Res. 2018, 29, 383-393. [CrossRef]

35. Peralbo-Molina, Á.; Luque deCastro, M.D. Potential of residues from the Mediterranean agriculture and agrifood industry. Trends Food Sci. Technol. 2013, 32, 16-24. [CrossRef]

36. Duca, D.; Toscano, G.; Pizzi, A.; Rossini, G.; Fabrizi, S.; Lucesoli, G.; Servili, A.; Mancini, V.; Romanazzi, G.; Mengarelli, C. Evaluation of the characteristics of vineyard pruning residues for energy applications: Effect of different copper-based treatments. J. Agric. Eng. 2016, 47, 22-27. [CrossRef]

37. Ronga, D.; Francia, E.; Allesina, G.; Pedrazzi, S.; Zaccardelli, M.; Pane, C.; Tava, A.; Bignami, C. Valorization of Vineyard By-Products to Obtain Composted Digestate and Biochar Suitable for Nursery Grapevine (Vitis vinifera L.) Production. Agronomy 2019, 9, 420. [CrossRef]

38. Kloss, S.; Zehetner, F.; Wimmer, B.; Buecker, J.; Rempt, F.; Soja, G. Biochar application to temperate soils: Effects on soil fertility and crop growth under greenhouse conditions. J. Plant Nutr. Soil Sci. 2014, 177, 3-15. [CrossRef]

39. Marshall, J.; Muhlack, R.; Morton, B.J.; Dunnigan, L.; Chittleborough, D.; Kwong, C.W. Pyrolysis Temperature Effects on Biochar-Water Interactions and Application for Improved Water Holding Capacity in Vineyard Soils. Soil Syst. 2019, 3, 27. [CrossRef]

40. Manyà, J.J.; Ortigosa, M.A.; Laguarta, S.; Manso, J.A. Experimental study on the effect of pyrolysis pressure, peak temperature, and particle size on the potential stability of vine shoots-derived biochar. Fuel 2014, 133, 163-172. [CrossRef]

41. Rosas, J.G.; Gómez, N.; Cara, J.; Ubalde, J.; Sort, X.; Sánchez, M.E. Assessment of sustainable biochar production for carbon abatement from vineyard residues. J. Anal. Appl. Pyrolysis 2015, 113, $239-247$. [CrossRef]

42. Azuara, M.; Sáiz, E.; Manso, J.A.; García-Ramos, F.J.; Manyà, J.J. Study on the effects of using a carbon dioxide atmosphere on the properties of vine shoots-derived biochar. J. Anal. Appl. Pyrolysis 2017, 124, 719-725. [CrossRef]

43. Manyà, J.J.; González, B.; Azuara, M.; Arner, G. Ultra-microporous adsorbents prepared from vine shoots-derived biochar with high $\mathrm{CO}_{2}$ uptake and $\mathrm{CO}_{2} / \mathrm{N}_{2}$ selectivity. Chem. Eng. J. 2018, 345, 631-639. [CrossRef]

44. Laghari, M.; Mirjat, M.S.; Hu, Z.; Fazal, S.; Xiao, B.; Hu, M.; Chen, Z.; Guo, D. Effects of biochar application rate on sandy desert soil properties and sorghum growth. Catena 2015, 135, 313-320. [CrossRef] 
45. Mohamed, W.; Hammam, A. Poultry manure-derived biochar as a soil amendment and fertilizer for sandy soils under arid conditions. Egypt. J. Soil Sci. 2019, 59, 1-14. [CrossRef]

46. ASTM International. American Standard of Testing Material: Standard Test Method for Chemical Analysis of Wood Charcoal; ASTM: West Conshohocken, PA, USA, 2001.

47. Van Soest, P.J.; Robertson, J.B.; Lewis, B.A. Methods for Dietary Fiber, Neutral Detergent Fiber, and Nonstarch Polysaccharides in Relation to Animal Nutrition. J. Dairy Sci. 1991, 74, 3583-3597. [CrossRef]

48. Greco, G.; Videgain, M.; Di Stasi, C.; González, B.; Manyà, J.J. Evolution of the mass-loss rate during atmospheric and pressurized slow pyrolysis of wheat straw in a bench-scale reactor. J. Anal. Appl. Pyrolysis 2018, 136, 18-26. [CrossRef]

49. Zucconi, F.; Pera, A.; Forte, M.; De Bertoldi, M. Evaluating toxicity of immatre compost. Biocycle 1981, 22, $54-57$.

50. Liang, C.; Gascó, G.; Fu, S.; Méndez, A.; Paz-Ferreiro, J. Biochar from pruning residues as a soil amendment: Effects of pyrolysis temperature and particle size. Soil Tillage Res. 2016, 164, 3-10. [CrossRef]

51. Hewitt, E.J. the Technical communication 22 (2nd revised edittion); Commonwealth Agricultural Bureaux, Farnham Royal: Bucks, UK, 1969; p. 547.

52. He, P.; Liu, Y.; Shao, L.; Zhang, H.; Lü, F. Particle size dependence of the physicochemical properties of biochar. Chemosphere 2018, 212, 385-392. [CrossRef] [PubMed]

53. Busch, D.; Kammann, C.; Grünhage, L.; Müller, C. Simple Biotoxicity Tests for Evaluation of Carbonaceous Soil Additives: Establishment and Reproducibility of Four Test Procedures. J. Environ. Qual. 2012, 41, 1023-1032. [CrossRef]

54. Buss, W.; Mašek, O. Mobile organic compounds in biochar-A potential source ofcontamination-Phytotoxic effects on cress seed (Lepidiumsativum) germination. J. Environ. Manag. 2014, 137, 111-119. [CrossRef]

55. Alotaibi, K.D.; Schoenau, J.J. Addition of biochar to a sandy desert soil: Effect on crop growth, water retention and selected properties. Agronomy 2019, 9, 327. [CrossRef]

56. Olmo, M.; Villar, R.; Salazar, P.; Alburquerque, J.A. Changes in soil nutrient availability explain biochar's impact on wheat root development. Plant Soil 2016, 399, 333-343. [CrossRef]

57. Ali, K.; Wang, X.; Riaz, M.; Islam, B.; Khan, Z.H.; Shah, F.; Munsif, F.; Ijaz Ul Haq, S. Biochar: An eco-friendly approach to improve wheat yield and associated soil properties on sustainable basis. Pakistan J. Bot. 2019, 51, 1255-1261. [CrossRef]

58. Sun, Y.; Gao, B.; Yao, Y.; Fang, J.; Zhang, M.; Zhou, Y.; Chen, H.; Yang, L. Effects of feedstock type, production method, and pyrolysis temperature on biochar and hydrochar properties. Chem. Eng. J. 2014, 240, 574-578. [CrossRef]

59. Liu, X.H.; Zhang, X.C. Effect of biochar on ph of alkaline soils in the Loess Plateau: Results from incubation experiments. Int. J. Agric. Biol. 2012, 14, 745-750.

60. Lehmann, J.; Da Silva, J.P.; Steiner, C.; Nehls, T.; Zech, W.; Glaser, B. Nutrient availability and leaching in an archaeological Anthrosol and a Ferralsol of the Central Amazon basin: Fertilizer, manure and charcoal amendments. Plant Soil 2003, 249, 343-357. [CrossRef]

61. Hailegnaw, N.S.; Mercl, F.; Pračke, K.; Száková, J.; Tlustoš, P. Mutual relationships of biochar and soil pH, CEC, and exchangeable base cations in a model laboratory experiment. J. Soils Sediments 2019, 19, 2405-2416. [CrossRef]

(C) 2020 by the authors. Licensee MDPI, Basel, Switzerland. This article is an open access article distributed under the terms and conditions of the Creative Commons Attribution (CC BY) license (http://creativecommons.org/licenses/by/4.0/). 